Research Article,

\title{
Oral Health Knowledge Among Of Student Elementary School in Sumedang City, Indonesia
}

\author{
Siti Sopiatin $^{1}$, Agus Susanto ${ }^{1}$, Prajna Metta ${ }^{1}$, Yanti Rusyanti ${ }^{1}$ \\ ${ }^{1}$ Department of Periodontics, Faculty of Dentistry, Unversitas Padjadjaran, Bandung
}

\begin{abstract}
Prevalence of dental and oral diseases in Indonesia is high and tend to continue to increase. This study aims to determine the level of oral health knowledge of grade V and VI students at Tanjungsari III Elementary School in Sumedang City.
\end{abstract}

Methods: This research is a quantitative descriptive study with cross-sectional research design using questionnaire. The study population was students at Tanjungsari III Elementary School with a total of 62 students (26 male and 36 female). Analysis of the data in this study was quantitative descriptive analysis techniques with percentages using three assessment categories, named: High, Medium, and Low.

Results: The results of the study of the level of knowledge about oral health of students mostly in the medium category amounted to $69.35 \%$ with a total of 43 students. Whereas in the high category it was $14.52 \%$ with a total of 9 students, the low category was $16.13 \%$ with a total of 10 students.

Conclusions: The level of oral health knowledge of the fifth and sixth grade students of Tanjungsari III Elementary School in Sumedang was the medium category. Continuous education and preventive measures to prevent oral diseases early were needed on elementary school students.

Key words: knowledge, oral health, elementary school

\section{Introduction:}

Poor oral hygiene status is a common condition in elementary school students. Poor dental hygiene status can be caused by a low level of oral health knowledge. Oral health is important but often neglected, even though the oral cavity is a "gateway" for bacteria or germs that can adversely affect other organs of the body. ${ }^{1}$ Oral health is part of overall body health that cannot be separated from health body. ${ }^{2}$ In 2012, WHO (World Health Organization) defined oral health as a condition free from mouth, face and throat cancer, mouth infections and wounds, gum and periodontal disease and disorders that limit an individual's capacity in chewing, biting, smiling, talking and psycho-social welfare. ${ }^{2}$ Data according to Riskesdas in 2007, oral health in Indonesia still requires attention; this can be seen from the high prevalence of dental and oral disease, which is about $90 \%$ of Indonesia's population. The prevalence of people who have dental and oral problems according to the Basic
Health Research (RISKESDAS) has increased. ${ }^{3}$ Oral health is not only about the teeth, but is also related to the supporting tissues of teeth and soft tissues in the mouth, tongue and lips. Oral disease is an important thing to note because it can cause tooth loss and affect general health through its influence on diet, pronunciation and worsening of existing chronic diseases such as diabetes and heart disease. ${ }^{1}$ Behavior is influenced by the presence or absence of health facilities and infrastructure as a supporting factor. Difficult access to health services and the absence of health office is one of the factors that affect the maintenance of oral health. The neighborhood also influences oral health behavior. The influence of the environment around the residence such as parents and teachers have an important role because the education provided by parents or teachers will have an impact on the behavior of a student. ${ }^{4,5}$

Oral health is very important because if the teeth and gums are damaged and not treated it can cause pain, mastication and can interfere with other 
health. Oral health problems are also very important, especially in elementary school age students. Primary school age is a good time to introduce knowledge and behaviors to maintain health so that it can become a habit in the future. ${ }^{6}$ Knowledge about oral health is important to explain to elementary school students from an early age so that it becomes a habit from an early age to always maintain dental health and mouth. In this study aims to determine the level of knowledge of oral health students of Tanjungsari Sumedang public elementary school III.

\section{Research methods}

This research is a descriptive study, which describes or illustrates the level of oral health knowledge of elementary school students. The sampling technique used was total sampling, so that the total number of class V and VI students at SDN III in Tanjungsari was 62 students. Subjects in this study were school-age children aged 10-13 years, understood Indonesian, could read and write, and were willing to participate in this study. The level of oral health knowledge was measured using a questionnaire, with multiple choice questions consisting of 22 multiple choice questions. Data from the questionnaire is categorized into "high", "medium" and "low" categories. The data obtained were analyzed in the form of a percentage using quantitative descriptive analysis techniques.

\section{Research result}

The study was conducted on 62 students consisting of 26 men and 36 women, with an age range of 10-13 years (table 1). The majority level of dental health knowledge in the medium category was $69.35 \%$, low category was $16.13 \%$, and the high category was $14.52 \%$ (table 2). The level of dental health knowledge by class and sex is presented in tables 3 and 4 .

Table 1: Characteristic of Respondents

\begin{tabular}{|l|l|}
\hline Characteristic of Respondents & n (\%) \\
\hline Age (Year) & $14(22,58)$ \\
$\mathbf{1 0}$ & $31(50,00)$ \\
$\mathbf{1 1}$ & $15(24,19)$ \\
$\mathbf{1 2}$ & $2(3,23)$ \\
$\mathbf{1 3}$ & \\
Sex & $26(41,93)$ \\
Male & $36(58,07)$ \\
Female & \\
Grade & $41(66,13)$ \\
V & $21(33,87)$ \\
VI & $62(100)$ \\
\hline Total & \\
\hline
\end{tabular}

Table 2: Level of Oral Health Knowledge of Tanjungsari III Elementary School Student

\begin{tabular}{|l|l|}
\hline Level of Knowledge & $\mathbf{n}(\boldsymbol{\%})$ \\
\hline High & $9(14,52)$ \\
\hline Medium & $43(69,35)$ \\
\hline Low & $10(16,13)$ \\
\hline Total & $62(100)$ \\
\hline
\end{tabular}

Table 3: Level of Oral Health Knowledge of Tanjungsari III Elementary School Students Based on Grade (V dan VI)

\begin{tabular}{|l|l|l|}
\hline $\begin{array}{l}\text { Level of } \\
\text { Knowledge }\end{array}$ & Grade V & Grade VI \\
\cline { 2 - 3 } & $\mathbf{n}(\%)$ & $\mathbf{n}(\%)$ \\
\hline High & $8(19,51)$ & $1(4,76)$ \\
\hline Medium & $29(70,73)$ & $14(66,67)$ \\
\hline Low & $4(9,76)$ & $6(28,57)$ \\
\hline Total & $41(100)$ & $21(100)$ \\
\hline
\end{tabular}

Table 4: Level of Oral Health Knowledge of Tanjungsari III Elementary School Students Based on Sex (Male and Female)

\begin{tabular}{|l|l|l|}
\hline Level of Knowledge & Male & Female \\
\cline { 2 - 3 } & $\mathbf{n}(\%)$ & $\mathbf{n}(\%)$ \\
\hline High & $3(11,54)$ & $6(16,67)$ \\
\hline Medium & $21(80,77)$ & $22(61,11)$ \\
\hline Low & $2(7,69)$ & $8(22,22)$ \\
\hline Total & $26(100)$ & $36(100)$ \\
\hline
\end{tabular}


Table 5: Distribution of Oral Health Knowledge of Tanjungsari III Elementary School Students

\begin{tabular}{|c|c|c|c|c|}
\hline \multirow[t]{2}{*}{ Statement } & \multicolumn{2}{|c|}{ Correct } & \multicolumn{2}{|c|}{ Incorrect } \\
\hline & $\mathrm{n}$ & $\%$ & $\mathrm{n}$ & $\%$ \\
\hline $\begin{array}{l}\text { Healthy teeth are teeth that } \\
\text { are clean and not hollow }\end{array}$ & 62 & 100 & 0 & 0 \\
\hline Healthy gums are pink gums & 61 & 98,4 & 1 & 1,6 \\
\hline $\begin{array}{l}\text { The cause of cavities is } \\
\text { bacteria / germs }\end{array}$ & 62 & 100 & 0 & 0 \\
\hline $\begin{array}{lll}\text { Toothache is not a } & \text { a } \\
\text { contagious disease } & & \end{array}$ & 54 & 87,1 & 8 & 12,9 \\
\hline $\begin{array}{l}\text { Everyone must have their } \\
\text { own toothbrush at home }\end{array}$ & 60 & 96,8 & 2 & 3,2 \\
\hline $\begin{array}{l}\text { The right time to brush your } \\
\text { teeth is after breakfast and } \\
\text { before going to bed at night }\end{array}$ & 34 & 54,8 & 28 & 45,2 \\
\hline $\begin{array}{l}\text { Brushing teeth at least } 2 \\
\text { times a day }\end{array}$ & 34 & 54,8 & 28 & 45,2 \\
\hline $\begin{array}{l}\text { The shape of the toothbrush } \\
\text { used should be a straight and } \\
\text { smooth brush }\end{array}$ & 54 & 87,1 & 8 & 12,9 \\
\hline $\begin{array}{l}\text { Brushing is done in a } \\
\text { circular motion about the } \\
\text { entire surface of the tooth }\end{array}$ & 19 & 30,6 & 43 & 69,4 \\
\hline $\begin{array}{l}\text { The initial symptoms of } \\
\text { cavities are aching when } \\
\text { consuming sweet foods / } \\
\text { drinks }\end{array}$ & 39 & 62,9 & 23 & 37,1 \\
\hline $\begin{array}{l}\text { If the cavities, go to the } \\
\text { dentist for fillings }\end{array}$ & 47 & 75,8 & 15 & 24,2 \\
\hline $\begin{array}{l}\text { Every cavity does not need } \\
\text { to be removed }\end{array}$ & 2 & 3,2 & 60 & 96,8 \\
\hline $\begin{array}{lcr}\begin{array}{l}\text { Brushing } \\
\text { regularly } \\
\text { toothpaste } \\
\text { cavities }\end{array} & \begin{array}{c}\text { your } \\
\text { with } \\
\text { can }\end{array} & \begin{array}{r}\text { teeth } \\
\text { fluoride } \\
\text { prevent }\end{array} \\
\end{array}$ & 42 & 67,7 & 20 & 32,3 \\
\hline $\begin{array}{l}\text { If you have a toothache, see } \\
\text { your dentist }\end{array}$ & 43 & 69,4 & 19 & 30,6 \\
\hline $\begin{array}{l}\text { If the cavities, even though } \\
\text { the tooth does not feel pain, } \\
\text { need to be patched }\end{array}$ & 38 & 61,3 & 24 & 38,7 \\
\hline $\begin{array}{l}\text { Check regularly to the } \\
\text { dentist every } 6 \text { months }\end{array}$ & 7 & 11,3 & 55 & 88,7 \\
\hline $\begin{array}{l}\text { Dental examinations are } \\
\text { carried out routinely }\end{array}$ & 8 & 12,9 & 54 & 87,1 \\
\hline $\begin{array}{l}\text { Brushing your teeth is } \\
\text { important }\end{array}$ & 62 & 100 & 0 & 0 \\
\hline $\begin{array}{l}\text { Brushing teeth must be done } \\
\text { regularly }\end{array}$ & 55 & 88,7 & 7 & 11,3 \\
\hline $\begin{array}{l}\text { Brushing your teeth should } \\
\text { use toothpaste }\end{array}$ & 62 & 100 & 0 & 0 \\
\hline $\begin{array}{l}\text { Toothbrushes must be } \\
\text { replaced regularly }\end{array}$ & 55 & 88,7 & 7 & 11,3 \\
\hline $\begin{array}{l}\text { Besides toothbrushes, dental } \\
\text { floss must also be used }\end{array}$ & 14 & 22,6 & 48 & 77,4 \\
\hline
\end{tabular}

\section{Discussion:}

Based on the results of this study, it was found that the level of knowledge about oral health of grade $\mathrm{V}$ and VI students of SD Negeri III
Tanjungsari Sumedang was generally in the moderate category $(69.35 \%)$ or more than half of the total number of respondents who had known about oral health. This shows that the level of oral health knowledge of Tanjungsari III Elementary students in general is quite good, but there is still a very poor level of student knowledge (16.13\%). The results of the Gayatri research (2018) state that the level of dental health knowledge in Kauman Elementary School is in the high (82.9\%) and low (17.1\%) categories. ${ }^{7}$ Research by Kurniastuti (2015) shows almost the same results, which is approximately $70 \%$ of Grabag Elementary School students Grabag Subdistrict Purworejo Regency has a level of knowledge of oral health in the moderate to high category. ${ }^{8}$ Students' knowledge about oral health is also influenced by information obtained through various internet, TV and book information media. Several factors that can affect the level of oral hygiene of a person include socioeconomic conditions, age, sex, environment, attitudes, and behavior related to oral health. ${ }^{8}$ Results of research by Sherlyta et al (2017) shows that the oral hygiene level of Mekarjaya elementary school students in Bandung Regency is 2.67 included in the medium category. ${ }^{9}$ Of the 22 questions, some of the questions that have been answered correctly $100 \%$ are questions about diseased teeth are clean and non-cavities, the cause of cavities is bacteria / germs, brushing is important, tooth brushing should use toothpaste. While some questions that are still many are wrong is the question of each tooth cavity does not need to be pulled, answered incorrectly by $96.8 \%$ of respondents. Routine checks to the dentist every 6 months as much as $88.7 \%$, checks to the dentist carried out routinely $87.1 \%$, and questions other than toothbrushes, dental floss should also be used as much as $77.4 \%$. From these data it can be concluded that the majority of respondents already know the cause of cavities, the importance of brushing their teeth, but actions to maintain dental health such as periodic control, the use of dental hygiene aids and dental care measures are still not understood. Another illustration is that most elementary school age students have understood the importance of maintaining oral health but are not yet accustomed to brushing teeth properly. One of the factors that affect oral health is health behavior. The behavior of maintaining positive oral hygiene, for example the habit of brushing teeth, on the contrary the negative behavior is not brushing teeth regularly, the condition of oral hygiene will be unfavorable 
which affects the declining of oral health. The level of oral hygiene of a child is related to the child's behavior in maintaining oral hygiene. The better the behavior of cleaning teeth, the better the level of oral hygiene. ${ }^{10}$ Knowledge plays a role in shaping a person's healthy behavior but there are also other factors that influence behavior such as attitudes, environmental influences and the availability of health facilities. ${ }^{11,12}$ School-age children have less motivation in performing dental care, if since the beginning children are accustomed to brushing their teeth regularly, it will be easy to maintain these habits until adulthood. ${ }^{13}$ In this study, the level of oral health knowledge of students by sex, students women tend to show a higher level of dental health knowledge than men, this is because female students pay more attention to personal hygiene. A person's knowledge about the behavior of maintaining healthy teeth and mouth often there is a disharmony. The behavior of people who visit dental health care facilities when they are in a state of severe toothache. Public awareness to seek treatment as early as possible is still low so that the behavior of visiting dental health service facilities is also lacking. In Indonesia, less than $7 \%$ of adults and $4 \%$ of students who have the awareness to visit dental health care facilities. ${ }^{14}$

\section{Conclusion:}

The level of oral health knowledge of the fifth and fifth grade students of Tanjungsari Sumedang Elementary School in the medium category requires continuous counseling and preventive efforts to prevent oral diseases early on in elementary school students.

\section{Thank-you note}

We would like to thank the Padjadjaran University DRPM for its support in community service activities at Tanjungsari Sumedang Public Elementary School.

\section{References:}

[1.] Bashirian, S., Seyedzadeh-Sabounchi, S., Shirahmadi, S., Soltanian, A. R., Karimishahanjarini, A., \& Vahdatinia, F. Sociodemographic determinants as predictors of oral hygiene status and gingivitis in schoolchildren aged 7-12 years old: A cross-sectional study. PloS one. 2018; 13(12), e0208886.

[2.] Malik I. Kesehatan gigi dan mulut. Bandung: Universitas Padjadjaran. 2008 Available: http://pustaka.unpad.ac.id/.
[3.] Riskesdas. Badan penelitian dan pengembangan kesehatan. Jakarta: Ministry of Health, Republic of Indonesia. (2007).

[4.] Rahayu, C., Widiati, S., \& Widyanti, N. Hubungan antara Pengetahuan, Sikap, dan Perilaku terhadap Pemeliharaan Kebersihan Gigi dan Mulut dengan Status Kesehatan Periodontal Pra Lansia di Posbindu Kecamatan Indihiang Kota Tasikmalaya. Majalah Kedokteran Gigi Indonesia. 2014; 21(1): 27-32.

[5.] Dianmartha, C., Kusumadewi, S., \& Kurniawati, D. P. Y. (2018). Pengetahuan terhadap perilaku perawatan kesehatan gigi dan mulut pada anak usia 9-12 tahun di SDN 27 Pemecutan Denpasar. ODONTO: Dental Journal. 2018; 5(2): 110-115.

[6.] Aritonang, I. Hubungan Karakteristik dan Tindakan Ibu dalam Pemeliharaan Kesehatan Gigi dengan Status Kesehatan Gigi dan Mulut Siswa di SD Kecamatan Medan Tuntungan" (Master's thesis).

[7.] Gayatri, R. W., \& Ariwinanti, D. Tingkat Pengetahuan Kesehatan Gigi Siswa Sekolah Dasar Negeri Kauman 2 Malang. Preventia: The Indonesian Journal of Public Health. 2018; 1(2).

[8.] Kurniastuti. Tingkat Pengetahuan Tentang Kesehatan Mulut dan Gigi Siswa Kelas IV Dan V TA 2014/2015 SD Negeri Grabag Kecamatan Grabag Kabupaten Purworejo Jawa Tengah.(2015)

[9.] Sherlyta, M., Wardani, R., \& Susilawati, S. Tingkat kebersihan gigi dan mulut siswa Sekolah Dasar Negeri di desa tertinggal Kabupaten Bandung Oral hygiene level of underdeveloped village State Elementary School students in Bandung Regency. Jurnal Kedokteran Gigi Universitas Padjadjaran. 2017; 29(1).

[10.] Hidayat, W. Pembekalan pengetahuan dan kemandirian dalam perawatan kesehatan gigi dan mulut masyarakat desa balingbing dan desa cidadap, kecamatan pagaden barat, Subang. Dharmakarya. 2016; 5(1). 
[11.] Kawuryan, U. Hubungan Pengetahuan Tentang Kesehatan Gigi dan Mulut Dengan Kejadian Karies Gigi Siswa SDN Kleco II Kelas V Dan VI Kecamatan Laweyan Surakarta (Doctoral Dissertation, Universitas Muhammadiyah, Surakarta). (2008)

[12.] Notoatmodjo S. Promosi kesehatan dan ilmu perilaku. Jakarta: Rineka Cipta. 2007. p. 140.

[13.] Dewanti. Hubungan tingkat pengetahuan tentang kesehatan gigi dengan perilaku perawatan gigi pada anak usia sekolah di SDN pondok cina 4 depok. Thesis. Depok: Universitas Indonesia. 2012

[14.] Lukihardianti, A. $85 \%$ Siswa Usia Sekolah Dasar Menderita Karies Gigi. (2011). 